\title{
An exploration study to find important factors influencing on social marketing
}

\author{
Naser Azad*, Mozhgan Pazouki and Somayeh Hozour
}

Department of Management, Islamic Azad University, South Tehran Branch, Tehran, Iran

\section{H R O N I C L E}

\section{Article history:}

Received May 12, 2013

Received in revised format

12 August 2013

Accepted 18 August 2013

Available online

August 242013

Keywords:

Social marketing

Purchase behavior

Marketing

\begin{abstract}
A B S T R A C T
Social marketing plays essential role on accessing better market share. It normally costs less than other marketing techniques and provides better way for market exposure. In this paper, we present an empirical study to detect important factors influencing social marketing in one of well-known providers of university entrance pre-test. The proposed study designs a questionnaire in Likert scale consists of 16 questions, distributes it among some students who use this kind of services. Cronbach alpha is calculated as 0.926. In addition, Kaiser-Meyer-Olkin Measure of Sampling Adequacy and Approx. Chi-Square are 0.882 and 2219.3, respectively. Based on the results of our survey, we have derived two factors including marketing drivers and feasibility study.
\end{abstract}

2013 Growing Science Ltd. All rights reserved.

\section{Introduction}

Social marketing is becoming a popular method to attract customers to networks. Social marketing is an essential component of marketing planning, it helps get more exposure to interested customers through network, and online review sites become important sources of information in tourism product purchases (Pelton, 2013). Spark et al. (2013) examined experimentally how source, content style, and peripheral credibility cues in online postings affect four consumer beliefs, and how those in turn affect behaviors and purchase intentions for an eco-resort. They compared tourists' posts to managers' posts, containing unclear versus specific content, and with or without peripheral certification logos. First, they examined impacted of tourists' beliefs about utility, trustworthiness, quality and corporate social responsibility on attitude toward the resort and buy intentions. Second, they examined the impact of source, content, and certification on the beliefs. The interactions were complex, but broadly tourists treat specific data posted by customers as most useful and trustworthy. Their buy intentions were impacted principally by their overall attitude toward the resort and their beliefs in its corporate 
social responsibility. Jeong et al. (2013) presented an online experiment to study how marketers could maximize desirable consumer responses to brand pages on social network sites (SNSs) through the strategic implementation of corporate social responsibility (CSR). They compared two kinds of CSR, cause-related marketing (CRM) and cause sponsorship (CS), and the control group (control). The results disclosed that CRM could lead to the biggest consumer intention to join the SNS brand page, followed by CS and control. In addition, CRM resulted in the bigger intention to invite friends to the brand page than either CS or control.

According to Palmer et al. (2013a), a long stream of literature has detected cognitive, emotional and evaluative dimensions of social identity where past studies tried to identity self-congruence of incoming tourists. They looked to make a contribution by investigating residents' identity and its association with their propensity to become advocates for inward tourism. They reported that affective components of identity had no impact on advocacy, but significant direct impacts of cognitive components were detected and also indirect impacts mediated by involvement with tourists. They concluded that advertising images presented by many tourism destination marketing organizations were incongruent with residents' identity. Cognitive identity resulted in stronger advocacy behaviors, and encouraged by bigger involvement of residents with tourism activities.

According to Prasad \& Holzinger (2013) implemented a critical management studies perspective to appraise the phenomenon of marketing corporate social responsibility (CSR). Views emerging from critical management studies were specifically beneficial for a project of this scope due to their capability to render visible the hidden ideologies, which were the corollary of corporate marketing of CSR initiatives. They concluded with a discussion of the contributions that a critical management investigation perspective could influence on to discourses regarding corporate marketing and CSR, and it could provide some consideration of the implications these arguments pose for practice.

There are contradictory and equivocal evidences for the effect of CSR, and more specifically environmental, initiatives on consumer behavior. Grimmer and Bingham (2013 examined the relationship between the perceived environmental performance of a company (PEP) and consumers' purchase intentions, and then determined whether this relationship was moderated by the degree of consumers' environmental involvement (EI) and by the relative price of company products. They reported that participants report higher purchase intention for products from high versus low PEP firms, and that participants' EI and product price could moderate this relationship. Those with high EI reported bigger purchase intention for high PEP firms and the reverse for low PEP firms, indicating that participants with high EI were more positively impacted by their perceptions of a company's environmental performance. However, participants were more likely to favor a high PEP firm when the relative price of a product was low versus high, irrespective of their level of EI. The strong relationship between companies' PEP and consumers' purchase intentions appeared that developing and managing an environmental brand image could deliver substantial benefits, as long as it is appropriately communicated to consumers, and as long as consumers observe the added value of making such purchases.

Wood and Fowlie (2013) explored the effect of relationships and social networks within a social marketing technique to community communications in the UK. An understanding of their importance and value in delivering cost-effective customer-oriented services has grown substantially in the current political climate of cost cutting and 'Big Society'. Specifically, it makes an assessment on the effectiveness of implementing innovative communications channels with community communicators playing an essential role to increase trust and positive perceptions of local government amongst resident networks in the London Boroughs of Sutton, Havering and Bexley.

Wang et al. (2013) explained that firms are capable to obtain consumer network data more easily now than ever before using mature computing technologies. Although marketers are more interested in 
social networks for WOM marketing, they previously disregarded the relative importance of understanding network structures. Therefore, they proposed an integrated method, the social network analysis (SNA) and web mining techniques, through which marketers could discover interest groups in virtual communities. They demonstrated how a framework utilized within social networks could be implemented to build a recommendation system and provided an instance of social network marketing applications. They contributed to marketing research techniques in terms of data collection and analysis. They also offered some managerial applications and implications in which marketers could effectively accesses and communicated with consumers in virtual communities.

Rapp et al. (2013) proposed a contagion impact of social media implementation across business suppliers, retailers, and consumers. After developing and validating social media usage measures at three levels-supplier, retailer, and customer, they examined social media contagion impacts and their ultimate effect on multiple performance measures. The conceptual framework and empirical results offered new insights into the contagion impacts of social media usage across the channel of distribution as well as important social effect mechanisms, which enhance these factors. Consistent with the predictions, social media implementation positively contributed to brand performance, retailer performance, and consumer-retailer loyalty. In addition, the impact of supplier social media usage on retailer social media usage and in turn on customer social media usage was moderated by brand reputation and service ambidexterity.

Palmer et al. (2013b) stated that previous studies recommend that marketing strategy could be developed and implemented to mobilize and configure the actions of firm actors, generating a set of stabilizing activities concentrated on the firm-customer dyad. They reported how social movements proactively enroll and mobilize a wide range of relevant actors into a network of influence. Zhu (2013) detected the influential users oriented to viral marketing based on online social networks. Sparks et al. (2013) provided an online travel reviews as persuasive communication by considering the effects of content type, source, and certification logos on consumer behavior.

\section{The proposed study}

For over three decades, university entrance exam has become the most important issue among almost all students who have finished their high schools in Iran. They must prepare themselves to take part in a one-day long exam to show their skills in various courses such as general and specialized materials. The general courses cover Persian literature, Arabic and English language skills and general knowledge on religion. The other exam includes questions on physics, mathematics, chemistry, etc. The exam covers all related materials tout in high schools and students must prepare themselves to answer all sorts of four-choice questions. Although there are millions of people who are interested in engineering and medical programs, only a few of them become eligible to enter the university in such programs. As we can observe, there is a need for students to attend some unofficial exams to examine their capabilities and detect their strengths and weakness. Ghalamchi is one of the pioneers who decided to give such exams in Iran and it has created a monopolized firm for giving such exams in Iran. The present study attempts to detect important factors influencing social marketing in this organization.

The proposed study designs a questionnaire in Likert scale consists of 16 questions, distributes it among some students who use this kind of services. Cronbach alpha is calculated as 0.926. In addition, Kaiser-Meyer-Olkin Measure of Sampling Adequacy and Approx. Chi-Square are 0.882 and 2219.3, respectively. Based on the results of our survey, we have derived two factors including marketing drivers and feasibility study. Since the questionnaire was sensitive to skewness and we have decided to reduce the questions to 13. The study uses principal component analysis and Table 1 demonstrates the summary of our findings on communalities. 
Table 1

The summary of communalities

\begin{tabular}{|c|c|c|}
\hline Variable & Initial & Extraction \\
\hline VAR00003 & 1.000 & .796 \\
\hline VAR00004 & 1.000 & .784 \\
\hline VAR00005 & 1.000 & .633 \\
\hline VAR00006 & 1.000 & .649 \\
\hline VAR00007 & 1.000 & .686 \\
\hline VAR00008 & 1.000 & .601 \\
\hline VAR00009 & 1.000 & .676 \\
\hline VAR00010 & 1.000 & .689 \\
\hline VAR00011 & 1.000 & .548 \\
\hline VAR00012 & 1.000 & .588 \\
\hline VAR00014 & 1.000 & .592 \\
\hline VAR00015 & 1.000 & .552 \\
\hline VAR00016 & 1.000 & .741 \\
\hline
\end{tabular}

Table 2 demonstrates the results of factor analysis on these factors.

Table 2

The summary of principal component analysis after rotation

\begin{tabular}{ccccccc}
\hline \multirow{2}{*}{ Component } & Total & \multicolumn{2}{c}{ Initial Eigenvalues } & \multicolumn{3}{c}{ Extraction Sums of Squared Loadings } \\
& \% of Variance & Cumulative \% & Total & \% of Variance & Cumulative \% \\
\hline 1 & 7.008 & 5.3 .911 & 5.3 .911 & 7.008 & 5.3 .911 & 5.3 .911 \\
2 & 1.527 & 11.746 & 65.657 & 1.527 & 11.746 & 65.657 \\
4 & .820 & 6.307 & 71.964 & & & \\
5 & .659 & 5.065 & 77.029 & & & \\
6 & .594 & 4.573 & 81.602 & & & \\
7 & .519 & 3.992 & 85.594 & & & \\
8 & .402 & 3.091 & 88.685 & & & \\
9 & .357 & 2.745 & 91.431 & & & \\
10 & .319 & 2.457 & 93.887 & & & \\
11 & .274 & 2.106 & 95.993 & & & \\
12 & .163 & 1.659 & 97.652 & & & \\
13 & .143 & 1.250 & 98.902 & & & \\
\hline
\end{tabular}

Beside the results of Table 2, we have looked at Scree plot to determine important factors and the results of figure and Table indicate that there were two factors.

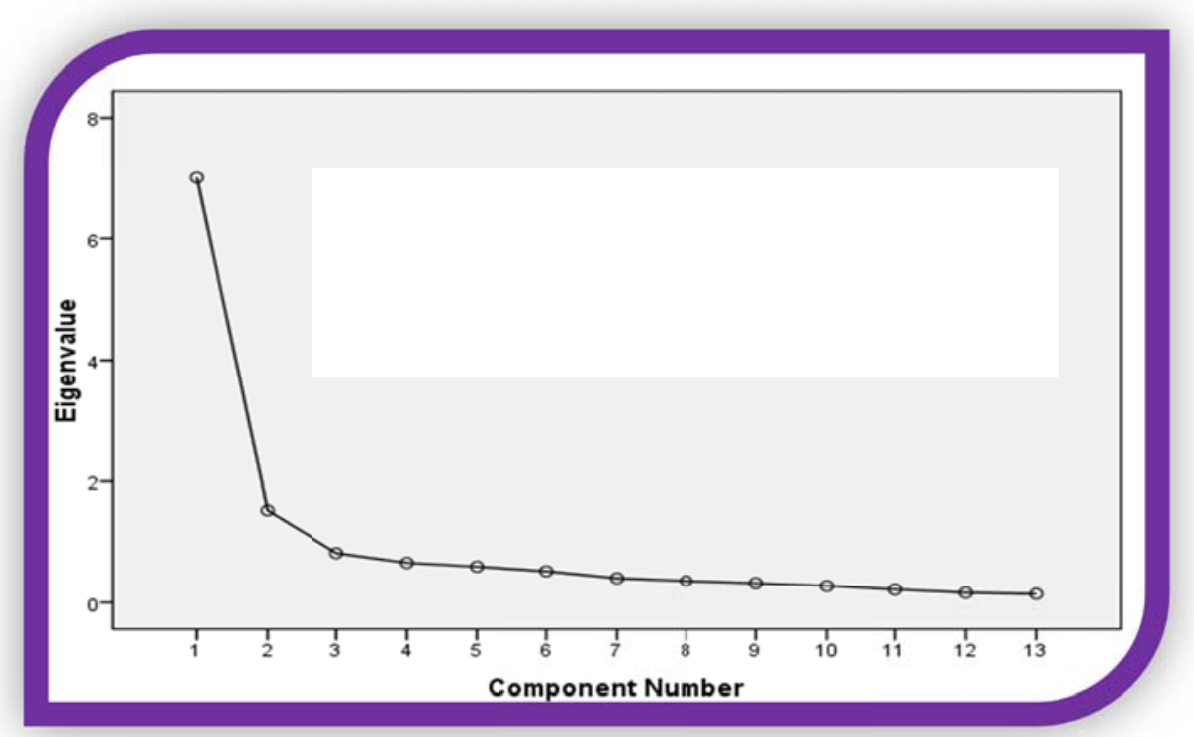

Fig. 1. The results of Scree plot 
Based on the results of our survey, we have derived two factors including marketing drivers and feasibility study. summarized in Table 3 as follows,

Table 3

The summary of factor analysis

\begin{tabular}{|c|c|c|c|c|c|}
\hline Factor & Measurable variable & Weight & Eigenvalue & Variance & Accumulated \\
\hline \multirow{10}{*}{ Marketing drivers } & Expenses & 0.844 & 2.489 & 62.223 & 62.223 \\
\hline & Marketing advertisement & 0.784 & & & \\
\hline & Price & 0.750 & & & \\
\hline & Marketing capabilities & 0.775 & & & \\
\hline & Power & 0.770 & & & \\
\hline & Product & 0.798 & & & \\
\hline & Information & 0.525 & & & \\
\hline & Public administration & 0.708 & & & \\
\hline & General advertisement & 0.520 & & & \\
\hline & Direct responsibility & 0.698 & & & \\
\hline \multirow{3}{*}{ Feasibility study } & Knowledge improvement & 0.728 & & & \\
\hline & Internet & 0.746 & 2.031 & 50.767 & 50.767 \\
\hline & Motivation & 0.726 & & & \\
\hline
\end{tabular}

\section{Discussion and conclusion}

The results of Table 3 indicate that there were two factors influencing social marketing on the proposed case study of this paper including marketing drivers and feasibility study. The first factor, marketing drivers, include 10 factors where total expenses as well as product and marketing advertisements are the most important factors followed by marketing capabilities, power of instruments used. Price is another important factor, which influences social marketing. In fact, price plays an essential role on other marketing planning problems. In our survey, public administration has also been another important factor, which influences marketing planning, substantially. The case study of this paper was associated with an organization, which was responsible for giving preuniversity exams. People who took part in our survey believed that having informative communication with this organization could be an essential start for them to start using their services.

Feasibility study is another important criterion, which influences our survey and it includes three factors including knowledge improvement, internet and motivation. The survey indicates that having fast, reliable and good internet services play essential role on having better exposure on the market.

\section{Acknowledgment}

The authors would like to thank the anonymous referees for their construction comments on earlier version of this work.

\section{References}

Grimmer, M., \& Bingham, T. (2013). Company environmental performance and consumer purchase intentions. Journal of Business Research, 66(10), 1945-1953.

Jeong, H. J., Paek, H., \& Lee, M. (2013). Corporate social responsibility effects on social network sites. Journal of Business Research, 66(10), 1889-1895.

Palmer, A., Koenig-Lewis, N., \& Medi Jones, L. E. (2013a). The effects of residents' social identity and involvement on their advocacy of incoming tourism. Tourism Management, 38, 142-151. 
Palmer, M., Simmons, G., \& Mason, K. (2013b). Web-based social movements contesting marketing strategy: The mobilisation of multiple actors and rhetorical strategies. Journal of Marketing Management.

Pelton, L. E. (2013). Critical social theory and the emancipation of marketing channels knowledge. Journal of Marketing Channels, 20(3-4), 204-223.

Prasad, A., \& Holzinger, I. (2013). Seeing through smoke and mirrors: A critical analysis of marketing CSR. Journal of Business Research, 66(10), 1915-1921.

Rapp, A., Beitelspacher, L. S., Grewal, D., \& Hughes, D. E. (2013). Understanding social media effects across seller, retailer, and consumer interactions. Journal of the Academy of Marketing Science, 41(5), 547-566.

Sparks, B. A., Perkins, H. E., \& Buckley, R. (2013). Online travel reviews as persuasive communication: The effects of content type, source, and certification logos on consumer behavior. Tourism Management, 39, 1-9.

Wang, K., Ting, I., \& Wu, H. (2013). Discovering interest groups for marketing in virtual communities: An integrated approach. Journal of Business Research, 66(9), 1360-1366.

Wood, M., \& Fowlie, J. (2013). Using community communicators to build trust and understanding between local councils and residents in the united kingdom. Local Economy, 28(6), 527-538.

Zhu, Z. (2013). Discovering the influential users oriented to viral marketing based on online social networks. Physica A: Statistical Mechanics and its Applications, 392(16), 3459-3469. 